\title{
PENERAPAN PRINSIP SYARIAH DALAM PEYELENGGARAAN LAYANAN PINJAM-MEMINJAM BERBASIS FINTECH
}

\author{
Basrowi \\ Sekolah Tinggi Ekonomi Bisnis Islam Lampung, Indonesia \\ Email: basrowi2018@gmail.com \\ Julianas \\ Universitas Islam Negeri Radin Inten Lampung, Indonesia \\ Email: air.tenang@gmail.com
}

\begin{abstract}
:
This study aims to describe the application of sharia principles in the implementation of fintech-based lending services. The method used in this study is descriptive qualitative research and literature. The data used is secondary data from various relevant and up to date literature. Based on the results of the analysis it can be concluded that accounts payable is an agreement between two parties giving money or goods to a second party to be utilized. In terms of engagement in accordance with Islamic law or according to sharia, contracts through information technology media still have to fulfill harmony and terms of contract. The contract scheme implemented by service providers includes the Wakalah bil Ujrah contract and the Musyarakah contract. In the field of muamalah known as the principle of Islamic law, namely the principle of skill or change. The terms of ljab Qobul must describe the agreement of the parties to enter into the online debt agreement. To achieve this, it is necessary to apply the principles of Islamic engagement, sharia, into financial transactions and other businesses that are consistently related.
\end{abstract}

Keywords: financial technology, sharia, principle

\section{PENDAHULUAN}

Indonesia sebagai salah satu negara dengan penduduk muslim terbesar di Asia memiliki potensi besar bermunculan platform fintech dan crowdfunding berbasis syariah. Namun perkembangannya disadari baru meningkat beberapa tahun belakangan(Pashafollow, 2017).

Bertransaksi secara syariah mempunyai berbagai kenyamanan, karena "Karakteristik bisnis syariah yang bersandar kepada pondasi ekonomi syariah yaitu ketuhanan (ilahiah), keadilan (al-adl), kenabian (an-nubuwah), pemerintahan (al-khalifah), dan hasil (almaad). Permintaan pengguna jasa layanan fintech berbasis syariah yang meningkat yang di dukung dengan pangsa pasar pengguna layanan dari masyarakat Indonesia yang mayoritas muslim mendorong Layanan Fintech berbasis syariah wajib memenuhi kaidah kaidah dalam transaksi bisnis secara syariah" (Alwi, 2018).

Setelah bisnis fintech pinjammeminjam konvensional meroket, kini fintech lending syariah mengekor yang turut meramaikan industri ini.Meski terbilang baru, setidaknya sudah ada beberapa perusahaan fintech lending syariah yang sedang mengurus pendaftaran ke Otoritas Jasa Keuangan (OJK) (Umi Kulsum, 2018). Mereka itu adalah Ammana Fintek Syariah, Dana Syariah, Investree Radhika Jaya, dan SyarQ. Sedangkan Ethis Crowd, Kapital Boost, Syarfi dan Danakoo Syariah masih 
dalam proses pengurusan perijinan. Menurut Kulsum, "Peminat fintech lending syariah bukan hanya muslim saja, tapi dari non-muslim pun tertarik, sehingga sudah menyalurkan pembiayaan syariah sebanyak Rp 2,7 miliar." (Umi Kulsum, 2018) Menurut Murniwati, "Produk konvensional mudah dijual dan mudah diakad-syariahkan, tapi itu harus dipandu fatwa. Perlu adanya alur-alur panduan bagi fintech dalam fatwa Dewan Syariah Nasional (DSN), sehingga audit syariah internal fintech pun dapat berjalan sejak awal." (Murniati, 2017).

Sebagaimana dijelaskan oleh Pashafollow, "Hukum syariah memiliki aturan dasar mengacu kepada Al- Qur'an dan Hadits. Setiap aktifitas mencari rezeki telah diatur dalam hukum syariah yang disepakati oleh para ulama. sistem keuangan juga diatur dalam hukum syariah mulai dari syarat hingga proses arus keuangan. Fintech syariah sebagai inovasi teknologi di bidang keuangan islam sepatutnya harus sejalan dengan hukum syariah." (Pashafollow, 2017).

Strategi yang diperlukan dalam kerangka pengembangan fintech Islam adalah "Kemampuan untuk mengelola dan menganalisis data di era big data, dan sumber daya manusia dalam pemasaran digital. Untuk aspek Ekosistem atau Aktor yang terlibat dalam pengembangan fintech Islam di Indonesia, aktor penting adalah: Pemerintah atau regulator, lembaga pendidikan (universitas), dan juga industri yang ada (bank dan lembaga keuangan lainnya)" (Samir \& Rahmizal, 2017).

Selain itu, penyelenggara Fintech Syariah juga harus, "Membangun sistem aplikasi yang baik sehingga benar-benar dapat dilaksanakan secara syariah, tanpa melanggar Al-quran maupun sunnah. Selanjutnya pihak yang masih terkait yaitu OJK dan Kemeninfokom. Kedua lembaga tersebut juga mempunyai andil yang sangat besar dalam membangun ekosistem fintech syariah di Indonesia." (Samir \& Rahmizal, 2017).

Otoritas Jasa Keuangan (OJK) telah mengeluarkan Peraturan OJK Nomor 77/POJK.01/2016 tanggal 29 Desember 2016 tentang Layanan Pinjam Meminjam Uang Berbasis Teknologi Informasi. Dalam peraturan tersebut disebutkan bahwa, "Layanan pinjam meminjam vang berbasis teknologi informasi adalah penyelenggaraan layanan jasa keuangan untuk mempertemukan pemberi pinjaman dengan penerima pinjaman dalam rangka melakukan perjanjian pinjam meminjam dalam mata uang rupiah secara langsung melalui sistem elektronik dengan menggunakan jaringan internet." (Mukhlisin, 2016).

Selanjutnya dijelaskan bahwa, "Dengan hanya $36 \%$ dari populasi yang memiliki rekening bank, fintech di Indonesia bermaksud memberikan layanan keuangan yang dapat diakses kepada populasi yang tidak memiliki bank di negara tersebut. ebagai populasi terbesar di dunia. Prospek fintech Islam di 
Indonesia tampak sangat cerah. Secara keseluruhan, fintech di Indonesia memiliki potensi besar dan besar karena dapat memberikan solusi untuk kebutuhan mendesak yang tidak dapat disediakan oleh lembaga kevangan tradisional. Selain itu, ledakan penetrasi seluler $(70$ persen menggunakan ponsel untuk mengakses web) di negara itu telah menciptakan lahan subur bagi kenaikan fintech yang cepat." (Samir \& Rahmizal, 2017).

Berdasarkan data OJK, "Total aset keuangan syariah Indonesia di luar saham syariah hingga Februari 2018 tercatat sebesar Rp1.117,88 triliun. Adapun posisi sukuk negara dalam pembagian aset syariah Indonesia mencapai Rp542 triliun, sedangkan total aset untuk perbankan syariah ialah Rp429,36 triliun. Sementara itu, besaran persentase untuk tiga aspek kevangan syariah juga tercatat mengalami peningkatan pada Februari 2018. Untuk besaran persentasenya, pasar modal syariah ialah 52,70 persen, perbankan syariah 38,40 persen, dan IKNB syariah 8,89 persen." (Andreas, 2018)

$\mathrm{Ke}$ depan dapat dipastikan, "Platform financial technology (fintech) berbasis syariah akan semakin banyak bermunculan. Perkembangan tersebut sejalan dengan peningkatan kesadaran masyarakat dalam bertransaksi halal sesuai syariah." (Pashafollow, 2017)

Sementara itu, dari aspek masalah dan tantangan yang dihadapi dalam pengembangan industri teknologi keuangan Islam, berikut adalah beberapa masalah: "(a) Kurangnya instrumen kebijakan menjaga proses kerja fintech dari hulu ke hilir (Pollari, 2016), (b) Kurangnya ketersediaan sumber daya manusia untuk fintech, (c) masalah Risiko keamanan yang tinggi dari serangan malware (Saksonova dan Merlino, 2017), (d) masalah ketidakpastian hukum pinjaman berbasis online, (e) masalah kemapuan fintech dalam menjangkau konsumen kelas bawah, (f) kurangnya pemahaman syariah, dan (g) perlunya peningkatan dalam aspek tata kelola, akuntansi dan audit syariah." (Samir \& Rahmizal, 2017).

Nienhaus memaparkan tentang, "Seputar kesulitan dalam mengembangkan fintech dalam lingkup syariah compliant. Perkembangan fintech dalam lingkup cryptocurrencies, peer to peer lending dan sejenisnya terhambat oleh batasan penerapan syariah. Dalam hal tersebut perlu pertanyaan spesifik yang lebih lanjut terkait hukum syariah dalam aspek teknologi yang disepakati para ulama." (Pashafollow, 2017)

Berdasarkan studi literatur, ada beberapa permasalahan berkaitan dengan pengembangan teknologi kevangan Islam dengan kerangka ISM dibagi menjadi empat kriteria: (1) Perspektif fungsi fintech, (2) masalah yang dihadapi dalam mengembangkan fintech Islam, (3) Strategi atau diperlukan dasar dalam kerangka pengembangan fintech Islam, dan (4) Ekosistem atau aktor yang 
terlibat dalam pengembangan fintech Islam di Indonesia (Samir \& Rahmizal, 2017).

Dari aspek strategi atau fondasi yang dibutuhkan dalam rangka pengembangan fintech Islam, khususnya di Indonesia, berikut adalah beberapa permasalahan di antaranya: (a) kemampuan mengelola dan menganalisis data di era big data, (b) peningkatan infrastruktur teknologi, (c) membuat sistem transaksi dengan mudah, (d) pemasaran berbasis konten dalam hal pemasaran digital, (f) membangun kerja sama, kolaborasi dan investasi dengan pemangku kepentingan terkait; (g) inovasi produk Fintech (Saksonova dan Merlino, 2017) (Samir \& Rahmizal, 2017).

Adapun aspek-aspek Ekosistem atau Aktor yang terlibat dan terkait dalam pengembangan fintech Islam di Indonesia adalah: "(a) pemerintah atau regulator, (b) industri fintech syariah, (c) industri yang ada (dalam hal ini bank dan lembaga keuangan lainnya), (d) modal ventura, (e) lembaga pendidikan (universitas), (f) penyedia infrastruktur jaringan/internet." (Samir \& Rahmizal, 2017)

Membaca permasalahan di atas, kajian ini hendak membahas tentang penerapan prinsip syariah dalam peyelenggaraan layanan pinjam meminjam berbasis fintech di Indonesia, prospek fintech syariah di Indonesia, dan hambatan pengembangan fintek syariah,

\section{LANDASAN TEORI}

Seiring perkembangan fintech syariah harus diikuti dengan keterbukaan pemerintah dalam membuat aturan yang mengakomodir inovasi teknologi keuangan. Sesuai dengan penelitian Nienhaus, terindikasi bahwa "Ada tiga model pembiayaan dan dua model pinjaman berbasis platform crowdfunding dan Cicilan Syariah yang masih aktif di beberapa negara Asia hingga tahun 2016. Indikasi tersebut memperlihatkan bahwa terdapat kesempatan besar untuk mengembangkan fintech syariah diikuti dengan aturan syariah yang jelas." (Pashafollow, 2017)

Menurut Murniati, "Fintech syariah adalah kombinasi inovasi di bidang financial (keuangan) dan technology(teknologi) dalam memudahkan proses transaksi dan investasi yang didasarkan pada nilai-nilai hukum islam (syariah)." (Murniati, 2017)

Shariah fintech, berarti "Teknologi keuangan sesuai dengan Hukum dan kepercayaan Islam. Fintech syariah jelas merupakan kata kunci baru untuk menggambarkan usaha teknologi kevangan ke dalam keuangan Islam. Beberapa bank Islam telah terbuka untuk mengadaptasi teknologi baru tersebut. Hasilnya adalah bahwa bukan bank syariah yang menjadi pendorong syariah fintech; tetapi startup, pengusaha dan perusahaan startup Islami yang mendorong perkembangan fintech tersebut. Mereka akan menjelasan mengapa inovasi fintech mereka halal, 
selanjutnya, fintech menjadi tidak dapat diterima hanya jika ada bukti yang jelas bahwa mereka bertentangan dengan aturan keuangan dasar Syariah." (Arno Maierbrugger, 2018)

Secara umum, keberadaan fintech telah mengganggu dan terbukti telah menjadi masalah bagi penyedia layanan keuangan yang sudah mapan seperti bank (Micu, 2016).

Dalam kriteria fungsi dan peran teknologi keuangan, beberapa fungsi fintech islam: "(a) transaksi keuangan online secara syariah, (b) vang elektronik syariah, (c) akun virtual syariah, (d) agregator syariah, (e) pinjaman dengan akad syariah, (f) pendanaan syariah, dan (g) perencanaan keuangan pribadi secara syariah." (Saksonova dan Merlino, 2017) (Samir \& Rahmizal, 2017).

Platform e-commerce berbasis syariah, "Langsung bisa memeriksa kelayakan kredit dari pembeli dan memiliki toleransi risiko kredit lebih tinggi dari bank konvensional. Akan tetapi ecommerce di Indonesia masih memprioritaskan pembayaran secara tunai. Terdapat juga fasilitas kredit, namun mengharuskan pembeli memiliki kartu kredit terlebih dahulu.SyarQ sebagai platform cicilan tanpa kartu kredit memiliki misi untuk menyelesaikan masalah ketidakmampuan masyarakat membeli barang di toko online. Platform ini menerapkan transaksi dengan akad murabahah yang sesuai dengan aturan syariah. Masyarakat dapat memenuhi kebutuhan secara kredit dan halal tanpa kartu kredit dengan sistem bunga." (Pashafollow, 2017).

Selanjutnya, "Manfaat dari FinTech dalam perbankan syariah yaitu kemudahan pelayanan finansial, hal ini karena proses transaksi keuangan menjadi lebih mudah dimana nasabah juga mendapatkan pelayanan finansial meliputi proses pembayaran, pembiayaan, transfer, ataupun jual beli saham dengan cara mudah dan aman. Nasabah dapat mengakses pelayanan finansial melalui teknologi seperti ponsel pintar maupun laptop. Sehingga tidak perlu datang langsung ke bank secara berulang-ulang untuk mendapatkan pembiayaan demi memenuhi berbagai kebutuhan. Kehadiran teknologi dalam urusan finasial seperti ini jelas membantu masyarakat dalam memaksimalkan layanan finansial. Masyarakat yang memerlukan produk finansial tertentu, cukup mengajukan melalui online. Kemudahan pelayanan finansial ini tercermin dari proses kerja yang tergolong cepat serta minimnya kebutuhan dokumen untuk mendapatkan produk finansial terkait." (Pashafollow, 2017).

Selanjutnya dijelaskan oleh (Muchlis, 2018).bahwa, "Fintech Syariah muncul karena ada permasalahan seputar system keuangan yang dapat diselesaikan dengan peran serta teknologi. Sebagai contoh, di sektor asuransi terdapat takaful (asuransi berbasis syariah) berperan sebagai 
platform dengan tujuan menciptakan kepercayaan antara pemegang polis dan perusahaan asuransi. Harapan besar dapat meningkatkan disiplin terkait klaim, mengurangi premi dan pembayaran tagihan."

Menurut Pashafollow dijelaskan bahwa, "Platform e-commerce berbasis syariah memiliki opsi tunai dan kredit sebagai penyedia jasa keuangan setara dengan Amazon atau Alibaba. Platform tersebut dapat menjual barang halal sesuai dengan hukum syariah. Cara transaksi barang terdapat dua macam, yaitu: 1) tunai 2) penundaan pembayaran (murabahah)." (Pashafollow, 2017).

\section{METODE PENELITIAN}

Dalam penelitian ini penulis menggunakan pendekatan Apabila dilihat dari jenisnya, penelitian ini adalah penelitian deskriptif (Busro, 2018). Metode analisis data dilakukan dengan menggunakan logika dedukti, dimana hasil analisis kemudian disajikan secara deskriptif, untuk disusun sebagai kesimpulan dalam menjawab permasalahan. Bahan primer yang digunakan meliputi Undang-Undang (UU), Peraturan Pemerintah (PP), Peraturan Bank Indonesia (PBI), Peraturan Otoritas Jasa Keuangan (POJK), Fatwa DSN. Bahan sekunder yang digunakan meliputi buku teks, jurnal ilmiah dan artikel ilmiah di internet. Bahan primer dan sekunder kemudian dianalisa untuk mencari keterkaitan dan kesesuaian dengan rumusan masalah dalam penelitian ini.

\section{HASIL DAN PEMBAHASAN}

\section{Konsep Utang Piutang menurut Syariah}

Istilah yang sering digunakan dalam utang piutang menurut bahasa Arab adalah, "al-dain dan al-qardh. Sebagai transaksi yang bersifat khusus, istilah yang lazim dalam fiqih untuk transaksi utang piutang khusus ini adalah al-qardh. Secara Bahasa al-qard berarti al-qoth' (terputus). Harta yang dihutangkan pada pihak lain disebut qardh karena ia terputus dari pemiliknya. Definisi yang berkembang dikalangan fuqaha yakni Al-Qard adalah penyerahan pemilikan harta al-mitsliyat kepada orang lain untuk ditagih pengembaliannya, atau dengan pengertian lain, suatu akad yang bertujuan untuk menyerahkan harta mitsliyat kepada pihak lain untuk dikembalikan yang sejenis dengannya." (Sari, 2018)

Qordh (utang piutang) adalah, "suatu akad antara dua pihak, di mana pihak yang pertama memberikan vang atau barang kepada pihak kedua untuk dimanfaatkan dengan ketentuan bahwa vang atau barang tersebut harus dikembalikan persis seperti yang ia terima dari pihak pertama. Baik Hanafiah maupun Hanabilah, keduanya memandang qordh sebagai harta yang diberikan oleh muqridh kepada muqtaridh yang pada suatu saat harus dikembalikan." (Sari, 2018)

Ketentuan Kitab Undang- Undang Hukum Perdata yaitu pada Pasal 1754 yang berbunyi "Pinjam meminjam adalah 
suatu perjanjian dengan mana pihak yang satu memberikan kepada pihak yang lain suatu jumlah tertentu barangbarang, dengan syarat bahwa pihak yang belakangan ini akan mengembalikan sejumlah yang sama dari macam dan keadaan yang sama pula."

Surat Al-Maidah Ayat 2 yaitu berkaitan dengan tolong menolong dalam hal kebajikan dan taqwa, bukan dalam hal yang bisa menimbulkan dosa. Hal ini diatur pada beberapa surat dalam Al-Qur'an sebagai berikut. Surat Al-Hadid Ayat 11:

من ذا الذى يقر ض الله قر ضا حسنا فيضعفه له وله اجر كر يم "Siapakah yang mau meminjamkan kepada Allah pinjaman yang baik, maka Allah akan melipat-gandakan (balasan) pinjaman itu untuknya, dan dia akan memperoleh pahala yang banyak". (QS $57: 11)$

Dalam surat Al Baqarah (2):276: "Allah memusnahkan riba dan menyuburkan sedekah dan Allah tidak menyukai setiap orang yang tetap dalam kekafiran dan selalu berbuat dosa." Dalam surat Al Baqarah (2) : 280: "Dan jika (orang berhutang itu) dalam kesukaran, maka berilah tangguh sampai dia berkelapangan. Dan menyedekahkan (sebagian atau semua hutang) itu lebih baik bagimu, jika kamu mengetahui." Dalam surat Al Baqarah (2) : 286: "Allah tidak membebani seseorang melainkan sesuai dengan kesanggupannya. la mendapat pahala (atas kebajikan) yang diusahakannya dan ia mendapat siksa (dari kejahatan) yang dikerjakannya".

"Dari kutipan ayat Al Quran diatas selalu digarisbawahi pentingnya sedekah dan tuntunan akan perlunya toleransi terhadap nasabah bila menghadapi nasabah sedang mengalami kesulitan (dalam arti sebenar-benarnya) membayar kembali kewajibannya. Hadits Nabi riwayat Muslim orang yang melepaskan seorang muslim dari kesulitannya di dunia, Allah akan melepaskan kesulitannya di hari kiamat; dan Allah senantiasa menolong hamba-Nya selama ia (suka) menolong saudaranya." (Trisadini P. Usanti, 2004).

Sementara dalam hadis Nabi Muhamad saw yang diriwayatkan Ibnu Majah, yang artinya sebagai berikut: "Dari Ibnu Mas'ud, sesungguhnya Nabi Besar Muhamad saw telah bersabda, Seorang Muslim yang mempiutangi seorang muslim dua kali, seolah-olah dia telah bersedekah kepadanya satu kali."

Adapaun yang menjadi rukun dan syarat dalam utang piutang adalah, "Meliputi: (Sari, 2018):

1. Adanya yang berpiutang (Muqridh) la adalah orang yang akan memberikan utang kepada pihak lain yang membutuhkan. Oleh karena itu, ia harus sudah cakap (ahliyah) melakukan perbuatan hukum dalam arti sudah dewasa, sehat akalnya, dan tidak terhalang untuk melakukan perbuatan hukum tersebut. 
2. Adanya orang yang berhutang (Muqtaridh) Pihak yang membutuhkan pinjaman vang. la juga telah cakap (ahliyah) melakukan perbuatan hukum.

3. Objek/barang yang diutangkan (Ma'qud 'Alaih) Barang yang dihutangkan disyaratkan berbentuk barang yang dapat diukur atau diketahui jumlah maupun nilainya. Disyaratkannya hal ini agar pada waktu pembayarannya tidak menyulitkan, sebab harus sama jumlah atau nilainya dengan jumlah atau nilai barang yang diterima.

4. Lafadz (Shigat/ljab dan Qobul) Adanya pernyataan baik dari pihak yang memberi utang maupun dari pihak yang akan menerima utang. Qordh adalah akad kepemilikan atas harta. Oleh karena itu akad tersebut tidak akan sah kecuali dengan adanya ijab dan qobul."

Dengan demikian dapat dipahami, utang piutang adalah akad antara dua pihak pemberi uang atau barang kepada pihak kedua untuk dimanfaatkan atau suatu perjanjian dengan mana pihak yang satu memberikan kepada pihak yang lain suatu jumlah tertentu barang-barang dengan syarat bahwa pihak yang belakangan ini akan mengembalikan sejumlah yang sama dari macam dan keadaan yang sama pula. Rukun dan syarat dalam utang piutang: adanya yang berpiutang (muaridh); orang yang berhutang (muqtaridh); objek/barang yang diutangkan (ma'qud 'alaih), dan lafadz (shigat/ijab dan qobul).

\section{Mekanisme Pinjam meminjam atau pembiayaan yang berdasar akad syariah}

"Mekanisme pinjam meminjam atau pembiayaan yang berdasar akad syariah dilakukan dengan mekanisme sebagai berikut:

$\begin{array}{rrr}\text { 1. Penerima } & \text { pinjaman } & \text { mengajukan } \\ \text { pinjaman } & \text { melaui } & \text { website }\end{array}$ penyelenggara layanan.

2. Penerima pinjaman mengirimkan berkas identitas.

3. Penerima pinjaman mengirimkan dokumen terkait kebutuhan pembiayaan seperti dokumen legalitas usaha, tagihan (Invoice) atas piutang usaha dan dokumen penunjang lainnya. Untuk menjaga prinsip Pembiayaan Syariah agar tetap pada koridornya, maka tidak semua invoice dapat diterima di untuk pinjam meminjam atau pembiayaan Syariah. Invoice yang berasal dari industri rokok, minuman keras, obat terlarang, babi, perjudian, prostitusi, hotel yang belum syariah, syariah, dan kegiatan yang mengandung spekulasi bukan merupakan pasar sasaran penyelenggara layanan berbasis Syariah. Jenis invoice yang menjadi prioritas adalah yang ditujukan kepada Payor berupa perusahaan besar, contohnya perusahaan multinasional, institusi yang terdaftar di bursa saham, atau instansi pemerintahan. 
4. Dokumen ini diperlukan oleh Penyelenggara layanan karena salah satu tujuan dari layanan ini adalah untuk mendukung pendanaan bagi usaha kecil (UMKM) sehingga mayoritas peyelenggara layanan meminta dokumen terkait dengan usaha penerima pinjaman. Namun untuk penerima pinjaman yang bersifat perorangan yang tidak memiliki usaha dokumen yang diberikan hanya terkait dengan sumber pengembalian biasanya berbentuk Slip gaji dan foto kopi rekening tabungan.

5. Pihak Penyelenggara melakukan skoring atau analisa terkait kelayakan pemberian pinjaman kepada calon penerima pinjaman sesuai dengan jangka waktu dan bunga pinjaman serta kemampuan pengembalian pembayaran oleh peminjam. Setelah mengeluarkan skoring dan masuk kategori layak diberikan pinjaman, penyelengara memberikan informasi kepada pemberi pinjaman bahwa terdapat pihak yang mengajukan pinjaman yang layak di berikan pinjaman serta siap melakukan akad pinjam meminjam.

6. Akad pembiayaan atau pinjam meminjam dilakukan antara penerima pinjaman dan pemberi pinjaman dengan skema Al Qardh.Pemberi pinjaman memberikan pinjaman atau talangan atas invoice yang diberikan, dilanjutkan dengan akad Wakalah bil ujrah, Pemberi pinjaman mewakilkan kepada penyelenggara layanan untuk membantu melakukan pengurusan atas invoice yang diberikan oleh peminjam. Akad Al Qardh maupun wakalah bi al-ujrah dilakukan secara online memalui website penyelenggara layanan. Dapat pula mempergunakan akad Musyarakah untuk segmentasi tertentu. Semua kegiatan akad yang dilakukan para antara pemberi pinjaman dan peminjam tunduk dan mengikuti ketentuan dalam UU ITE dan hukum perikatan pada umumnya.

7. Penerima pinjaman memberikan jaminan berupa invoice (tagihan) serta giro mundur sesuai tanggal jatuh tempo pinjaman. Untuk pinjaman perorangan pemberi pinjaman dapat meminta jaminan lain sesuai kesepakatan para pihak.

8. Pinjaman dicairkan melalui rekening Virtual penerima pinjaman pada Bank yang sudah ditunjuk dan bekerjasama dengan peyelenggara layanan." (Alwi, 2018).

Akad Merupakan "Ikatan antara dua perkara, baik ikatan secara nyata maupun secara maknawi, dari satu segi maupun dua segi. Sedangkan secara terminologis ulama fikih ditinjau dari dua segi yaitu secara umum dan secara khusus. Secara umum definisi akad dalam arti luas hampir sama dengan pengertian akad dari segi bahasa menurut pendapat ulama Mazhab Syafii, Maliki dan Hambali yaitu segala sesuatu yang dikerjakan oleh seseorang berdasarkan keinginannya 
sendiri seperti wakaf, talak, pembebasan, atau sesuatu yang pembentukannya membutuhkan keinginan dua orang seperti jual beli, perwakilan dan gadai. Sedangkan pengertian akad dalam arti khusus yang dikemukakan oleh ulama fikih, antara lain, ikatan antara ljab dan Kabul berdasarkan ketentuan syara yang berimplikasi pada objeknya" (M. Ali Hasan, 2018).

Online contract meskipun merupakan fenomena yang baru namun masih berlaku asas asas hukum kontrak pada umumnya maupun hukum kontrak sesuai syariah. Dalam segi perikatan sesuai hukum Islam atau sesuai syariah, kontrak melalui media teknologi informasi tetap harus memenuhi rukun dan syarat akad.

Pada Pasal 21 Peratuaran Mahkamah Agung Nomor 2 Tahun 2008 tentang kompilasi Hukum Ekonomi Syariah disebutkan bahwa, "Akad dilakukan berdasarkan asas, yaitu:

1. Iktiyari/Sukarela; setiap akad dilakukan atas kehendak para pihak, terhindar dari keterpaksaan karena teknan salah satu pihak atau pihak lain.

2. Amanah/Menepati janji; setiap akad wajib dilakasanakan oleh para pihak sesuai dengan kesepakatan yang di tetapkan oleh yang bersangkutan saat yang sama terhindar dari cidera janji.

3. IKtiyati/Kehati hatian; setiap akad dilakukan dengan pertimbangan yang matang dan dilaksanakan secara tepat dan cermat.
4. Luzum/Tidak Berubah; setiap akad dilakukan dengan tujuan yang jelas dengan perhitungan yang cermat sehingga terhindar dari praktik spekulasi atau maisir.

5. Saling Menguntungkan, setiap akad dilakukan untuk memenuhi kepentingan para pihaksehingga mecegah dari praktik manipulasi dan merugikan salah satu pihak.

6. Tsawiyah/Kesetaraan, para pihak dalam setiap akad memiliki kedudukan yang setara dan mempunyai hak dan kewajiban yang seimbang.

7. Transparansi, setiap akad dengan pertanggungjawaban para pihak yang seimbang. Kemampuan; setiap akad dilakukan sesuai dengan kemampuan para pihak, sehingga tidak menjadi beban yang berlebihan bagi yang bersangkutan.

9. Taisir/Kemudahan; setiap akad dilakukan dengan cara saling memberi kemudahan kepada masing masing pihak untuk dapat melaksanakannya sesuai dengan kemampuannya.

10. Itikad baik; akad dilakukan dalam rangka menegakkan kemaslahatan, tidak mengandung unsur jebakan dan perbuatan buruk lainnya.

11. Sebab yang halal; tidak bertentangan dengan hukum, tidak dilarang oleh hukum dan tidak haram." (M. Ali Hasan, 2018)

Jadi, mekanisme pinjam meminjam yang berdasar akad syariah dilakukan dengan mekanisme: 
mengajukan pinjaman melaui website penyelenggara layanan, pengiriman dan pengisian berkas identitas, pengiriman dokumen terkait, pihak Penyelenggara melakukan skoring atau analisa, dilanjutkan dengan dkad pembiayaan, penerima pinjaman memberikan jaminan berupa invoice, pinjaman dicairkan melalui rekening. Dalam segi perikatan sesuai hukum Islam atau sesuai syariah, kontrak melalui media teknologi informasi tetap harus memenuhi rukun dan syarat akad. Akad dilakukan berdasarkan asas, yaitu: iktiyari/sukarela; amanah/menepati janji; iktiyati/kehati hatian; IUzum/tidak berubah; saling menguntungkan; tsawiyah/kesetaraan, transparansi, taisir/kemudahan; itikad baik; dan sebab yang halal.

\section{Penerapan Prinsip Pinjam Meminjam pada Fintech Syariah}

Menurut Alwi, "Penyelengaraaan layanan pinjam meminjam berbasis teknologi informasi yang mempergunakan akad syariah memberikan beberapa pilihan kepada para pengguna layanan baik itu peminjam maupun pihak yang memberikan pinjaman. Peminjam maupun pemberi pinjaman diberikan skema sesuai kebutuhan mereka namun tetap sesuai koridor syariah. Penerapan skema syariah yang dilakukan penyenggara wajib memperhatikan ketentuan yang ditetapkan oleh regulator agar memberikan pelayanan yang maksimal serta perlindungan dan kepastian bagi pengguna layanan." (Alwi, 2018).

Menurut Trisadini dan Shomad, bahwa "Skema Akad yang di terapkan oleh penyelenggara layanan berbeda beda tergantung dengan skema dan kebutuhan penerima pinjaman. Beberapa akad yang di terapkan oleh penyelenggara layanan antara lain akad Wakalah bil Ujrah dan akad Musyarakah. Akad wakalah bil ujrah pada layanan pinjam meminjam vang berbasis teknologi informasi dapat diterapkan dalam proses penyaluran pembiayaan Invoice finacing. Invoice yang ajukan oleh borrower (peminjam) adalah tagihan yang berasal dari usaha disektor yang halal atau perbolehkan secara syariah, serta dari perusahaan atau instansi yang tergolong baik dalam segi keuangan dan kemampuan bayar. Lender (pemberi pinjaman) melalui Investree mengambil alih tagihan tersebut dengan melakukan pembayaran kepada borrower atas tagihan tersebut. Peminjam memperoleh keuntungan dengan menerima pembayaran terlebih dahulu dari Invoice tersebut. Sedangkan pemberi pinjaman memperoleh keuntungan berupa ujrah atas jasa talangan atau pembayaran terlebih dahulu kepada peminjam." (Trisadini UP dan Abdul Shomad, 2015)

Penyelenggaran layanan fintech Syariah dengan mempergunakan skema syariah tidak bertentangan dengan ketentuan yang ada dalam POJK Nomor 77/POJK.01/2016 yang menjadi dasar 
penyelenggaran layanan pinjam meminjam berbasis teknologi informasi. "Dalam pelaksaan transaksi syariah lembaga jasa keuangan wajib tunduk pada peraturan peraturan penyelenggaran layanan berdasar syariah yang dikeluarkan oleh pihak terkait Dalam hal pelaksanaan layanan pinjam meminjam berbasis teknologi informasiwajib me miliki payung hukum sebagai dasar pelaksanaan layanan pinjam meminjam berbasis teknologi informasi yang berdasarkan syariah. Sampai saat ini Otoritas Jasa Kevangan maupun Dewan Syariah Nasional Majelis Ulama Indonesia melum menerbitkan peraturan atau fatwa terkait penyelenggaraan layanan pinjam meminjam berbasis teknologi informasi yang berdasarkan syariah." (Adrian Sutedi, 2009)

Namun setelah terbit fatwa No 117/DSN-MUI/II/2018 Tentang Layanan Pembiayaan Berbasis Teknologi Informasi Berdasarkan Prinsip Syariah, "penyelenggaraan layanan yang wajib mengikuti ketentuan tersebut. Penyelenggaraan layanan wajib memenuhi ketentuan dan menyesuaikan penyelenggaran layanan dengan ketentuan syariah yang berkaitan dengan usaha tersebut. Kepatuhan terhadap prinsip syariah merupakan kewajiban bagi lembaga jasa keuangan yang menjalankan usahanya dengan prinsip syariah. Dalam peyelenggaraan kegiatan layanan Lembaga Jasa Keuangan Syariah wajib meperhatikan hal hal berikut antara lain Jaminan kepatuhan syariah (shariah compliance assurance) atas keseluruhan aktivitas penyelenggara Layanan. Hal ini merupakan salah satu yang sangat penting bagi pengguna layanan." (Alwi, 2018)

Beberapa ketentuan yang dapat digunakan sebagai, "Ukuran secara kualitatif untuk menilai ketaatan syariah bagi penyelenggara layanan pinjam meminjam berbasis teknologi informasi:

a. Akad atau kontrak yang digunakan untuk pengumpulan dan penyaluran pembiayaan sesuai dengan prinsipprinsip Syariah dan aturan Syariah yangberlaku.

b. Dana zakat dihitung dan dibayar serta dikelola sesuai dengan aturan danprinsip-prinsip syariah.

c. Seluruh transaksi dan aktivitas ekonomi dilaporkan secara wajar sesuaidengan standar akuntansi syariah yang berlaku.

d. Lingkungan kerja dan corporate culture sesuai dengan syariah.

e. Bisnis usaha yang dibiayai tidak bertentangan dengan Syariah.

f. Terdapat Dewan pengawas Syariah sebagai pengarah syariah atas seluruh kegiatan operasional penyelenggara layanan.

g. Semua dan berasal dari sumber yang sah dan halal sesuai syariah." (Adrian Sutedi, 2009)

Konsep dasar yang dilakukan pada utang piutang secara online adalah pada perjanjiannya yang dibuat secara 
online contract yang pada prinsipnya sama dengan perjanjian pada umumnya. Perbedaanya hanya terletak pada media yang digunakan untuk membuat perjanjian tersebut. Perjanjian jenis ini sering menggunakan fasilitas EDI (Electronic Data Interchange) yaitu suatu mekanisme pertukaran data secara elektronik yang umumnya berupa informasi bisnis yang rutin diantara beberapa komputer dalam suatu susunan jaringan komputer yang dapat mengelolanya. Data tersebut dibentuk menggunakan aturan standart sehingga dapat dilaksankan langsung oleh kompter atau media elektronik penerima (Sari, 2018)

Dalam bidang muamalah dikenal suatu asas Hukum Islam yaitu asas kebolehan atau mubah. Asas ini menunjukkan kebolehan melakukan semua hubungan perdata (sebagian dari hubungan muamalah) sepanjang tidak dilarang oleh Al-Qur'an dan As-Sunnah. Hal ini berarti bahwa Islam memberikan kepada yang berkepentingan untuk mengembangkan bentuk dan macammacam hubungan keperdataan (baru) sesuai dengan perkembangan zaman dan kebutuhan manusia sebagaimana dalam QS Al-Baqarah Ayat 185,103 Allah SWT berfiman: "...Allah menghendaki kemudahan bagimu, dan tidak menghendaki kesukaran bagimu.." (Trisadini UP dan Abdul Shomad, 2015)

Mengenai Maudhu'ul Aqdi atau tujuan dari akad dari perjanjian utang piutang yang akadnya dilakukan secara online harus dipenuhi syarat-syarat agar tujuan akad tersebut dipandang sah dan mempunyai akibat hukum. Selain itu, syarat ljab Qobul harus menggambarkan adanya kesepakatan para pihak untuk melakukan perjanjian utang piutang secara online tersebut (fintech berbasis P2P Lending). Persyaratan mengenai ijab qobul dalam perjanjian tesebut adalah jelasnya ijab dan qobul (jala'ul ma'an), kesesuaiannya antara ijab dan qobul (ittishal al qabul bil ijab/tawafuq), dan menunjukkan kehendak para pihak (jazmul iradataini)" (Sari, 2018)

Aspek kesesuaian dengan prinsip syariah merupakan, "Aspek yang mendasar dan menjadikan pembeda antara Penyelenggara layanan konvensional dengan penyelenggaran layanan berdasar syariahkarena dalam syariah tidak hanya profit oriented, namun juga falah oriented dimana tidak hanya keuntungan semata mata yang di peroleh namun kemenangan didunia dan di akhirat menjadi salah satu yang ingin dicapai dalam penyelenggaraan layanan. Untuk mencapai hal tersebut, maka dalam peraturan lembaga jasa keuangan syariah diatur mengenai kepatuhan syariah (syariah compliance) yang kewenangannya beradapada Majelis Ulama Indonesia yang direpresentasikan melalui Dewan PengawasSyariah yang harus dibentuk pada masing- masing Penyelenggara Layanan pinjam meminjam berbasis 
teknologi informasi yang berdasar syariah." (Alwi, 2018).

Kepatuhan Syariah merupakan, "Prinsip utama yang harus dipenuhi sekaligus pembeda dengan Penyelenggara Layanan jasa keuangan yang lain (Konvensional) sebagai bentuk perlindungan hukum preventif bagi para pengguna jasa layanan. Makna kepatuhan syariah dalam bank syariah secara konsep sesungguhnya adalah penerapan prinsip-prinsip perikatan Islam, syariah, dan tradisinya ke dalam transaksi keuangan serta bisnis lain yang terkait secara konsisten, dan menjadikan syariah sebagai kerangka kerja bagi sistem dan keuangan penyelenggara jasa keuangan syariah dalam alokasi sumberdaya, manajemen,produksi, aktivitas pasar modal, dan distribusi kekayaan. Dengan kata lain kepatuhan syariah dalam layanan pinjam meminjam berbasis teknologi informasi adalah tercipta dan terpenuhinya budaya kepatuhan pada prinsip syariah serta perundang-undangan yang berlaku.dalam bidang muamalah (transaksi fintech berbasis syariah) termasuk moral etika dalam setiap aktivitasnya." (Trisadini UP dan Abdul Shomad, 2015)

Dengan demikian, skema akad yang diterapkan penyelenggara layanan antara lain akad Wakalah bil Ujrah dan akad Musyarakah. Penyelenggaran layanan fintech Syariah dengan mempergunakan skema syariah tidak bertentangan dengan ketentuan yang ada. Dalam pelaksaan transaksi syariah lembaga jasa keuangan wajib tunduk pada peraturan peraturan penyelenggaran layanan berdasar syariah yang dikeluarkan oleh DSN No 117/DSN-MUI/II/2018 Tentang Layanan Pembiayaan Berbasis Teknologi Informasi Berdasarkan Prinsip Syariah. Konsep dasar yang dilakukan pada utang piutang secara online Perjanjian jenis ini sering menggunakan fasilitas EDI (Electronic Data Interchange). Dalam bidang muamalah dikenal suatu asas Hukum Islam yaitu asas kebolehan atau mubah. Asas ini menunjukkan kebolehan melakukan semua hubungan muamalah sepanjang tidak dilarang oleh Al-Qur'an dan As-Sunnah. Syarat ljab Qobul harus menggambarkan adanya kesepakatan para pihak untuk melakukan perjanjian utang piutang secara online tersebut. Untuk mencapai hal tersebut, maka perlu penerapan prinsip-prinsip perikatan Islam, syariah, ke dalam transaksi keuangan serta bisnis lain yang terkait secara konsisten.

\section{SIMPULAN}

Berdasarkan hasil analisis di atas dapat disimpulkan:

1. Utang piutang adalah akad antara dua pihak pemberi vang atau barang kepada pihak kedua untuk dimanfaatkan. Rukun dan syarat dalam utang piutang: adanya yang berpiutang (muqridh); orang yang berhutang (muqtaridh); objek/barang 
yang diutangkan (ma'qud 'alaih), dan lafadz (shigat/ijab dan qobul).

2. Mekanisme pinjam meminjam yang berdasar akad syariah dilakukan dengan mekanisme: mengajukan pinjaman melaui website penyelenggara layanan, pengiriman dan pengisian berkas identitas, pengiriman dokumen terkait, pihak penyelenggara melakukan skoring atau analisa, dilanjutkan dengan akad pembiayaan, penerima pinjaman memberikan jaminan berupa invoice, pinjaman dicairkan melalui rekening. Akad dilakukan berdasarkan asas: iktiyari/sukarela; manah/menepati janji; iktiyati/kehati hatian; luzum/tidak berubah; saling menguntungkan; tsawiyah/kesetaraan, transparansi, taisir/kemudahan; itikad baik; dan sebab yang halal.

3. Skema Akad yang diterapkan penyelenggara layanan antara lain akad Wakalah bil Ujrah dan akad Musyarakah. Penyelenggaran layanan fintech Syariah dengan mempergunakan skema syariah tidak bertentangan dengan ketentuan yang ada. Dalam pelaksaan transaksi syariah lembaga jasa keuangan wajib tunduk pada DSN No 117/DSNMUI/II/2018 Tentang Layanan Pembiayaan Berbasis Teknologi Informasi Berdasarkan Prinsip Syariah.

\section{DAFTAR PUSTAKA}

Adrian Sutedi. (2009). Perbankan Syariah: Tinjauan dan Beberapa Segi
Hukum. Jakarta: Ghalia.

Alwi, A. B. (2018). Pembiayaan Berbasis Teknologi Informasi (Fintech) yang Berdasarkan Syariah. Al-Qanun: Jurnal Pemikiran Dan Pembaharuan Hukum Islam, 21 (2), 255-271. Retrieved from http://jurnalfsh.uinsby.ac.id/index.p hp/qanun/article/view/684

Andreas, D. (2018). OJK Bakal Segera Buat Aturan untuk Mengawasi Fintech Syariah. Retrieved from https://ummatpos.com/19750/finte ch-syariah-butuh-landasan-fatwadan-panduan-ulama

Arno Maierbrugger. (2018). A new term is born: Shariah fintech, and it has quite some potential. Retrieved from https://www.gulftimes.com/story/599050/A-newterm-is-born-Shariah-fintech-and-ithas-quit\%0AA

Busro, Muhammad. 2018. Metode Penelitian Sosial. Surabaya: Jenggala Pustaka Utama

Dewan Syariah Nasional (DSN) No 117/DSN-MUI/II/2018 Tentang Layanan Pembiayaan Berbasis Teknologi Informasi Berdasarkan Prinsip Syariah

M. Ali Hasan. (2018). Pengantar Lembaga Kevangan Syariah. Surabaya: FH UNAIR SURABAYA. Retrieved from https://genap2019.aula.unair.ac.id /login/index.php Usanti,

Micu, A. (2016). Fintech And Its Implementation On The Romanian 
Non-Banking, IV(2), 379-384.

Retrieved from

seaopenresearch.eu/Journals/artic les/SPAS_11_30.pdf

Muchlis, R. (2018). Analisis SWOT Financial Technology (Fintech) Pembiayaan Perbankan Syariah Di Indonesia (Studi Kasus 4 Bank Syariah Di Kota Medan). AT-TAWASSUTH: Jurnal Ekonomi Syariah, 1 (1), 335-357.

Mukhlisin, M. (2016). Dibalik FinTech Syariah. Retrieved from https://www.islampos.com/5584555845/\%0ADibalik

Murniati. (2017). Fintech Syariah Butuh Landasan Fatwa Dan Panduan Ulama. Retrieved from https://ummatpos.com/19750/finte ch-syariah-butuh-landasan-fatwadan-panduan-ulama/\%0AFintech

Pashafollow, M. R. (2017). Potensi Besar Perkembangan Fintech Berbasis Syariah di Masa Depan.

Samir, S., \& Rahmizal, M. (2017). Developing Islamic Financial Technology In Indonesia, 1 (2), 130140.

https://doi.org/10.26487/hebr.v

Sari, A. R. (2018). Perlindungan Hukum Bagi Pemberi Pinjaman Dalam Penyelenggaraan Financial Technology Berbasis Peer To Peer Lending Di Indonesia. Yogyakarta. Retrieved from http://ejournal.vajy.ac.id/14649/1/Jurnal.p df

Trisadini P. Usanti. (2004). Penanganan
Pembiayaan Bermasalah Di Bank Syariah. Yuridika, 19(1).

Trisadini UP dan Abdul Shomad. (2015). Hukum Perbankan. Surabaya: FHUniversita Airlangga dan Lutfansah Media.

Umi Kulsum. (2018). Dewan Syariah dan OJK segera rilis fatwa fintech syariah, (November 2017), 2018. 